臨床ノート特別企画

\title{
第36回総会シンポジゥム「顔面外傷」（会長：黒住静之 広島大学教授）
}

とくに耳鼻咽喉科医に必要な基本的知識について

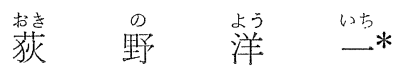

顔面外傷はその部位が人の目につくところに 生ずる損傷であるが故に肉体的並びに精神的苦 痛は著しく，且つまた顔面には各種の重要な機 能をもつ器官が多く集っているだけに外傷によ る機能的障害が患者の日常生活に与える影響は 大きい，従って各種の訴光をもって耳鼻科医を 訪れる顔面外傷患者の数も少なくない。

そこで耳鼻咽喉学における研究並びに臨床に おける重要な分野の一つとして耳鼻科医が当然 これと取り組まねばなら奴課題であると考光 る。

しかるに最近この分野に関連する耳鼻科医の 関心は少なく，積極的にとの種の問題をとりあ げている学会発表や学術論文をみることができ ない。

このことは日常の喎床に打ける耳鼻科医の態 度にもうかがい知るととができる。私共の郚床 に紹介されて来万各種の程度の顔面外傷患者か ら病歴を聴取してみると，耳鼻科㯺床医の許を 訪れるとすぐ，乙れは自らの手には到底負え奴 加「○○病院，○○大学病院の○○先生の許 へすぐ行きなさい」といわれてほとんど大した 処置も受けずに紹介されて来ている。

私はむしろ救急病院の外科などで粗潾な創傷 処理や縫合をうけるよりは舅腔内の損傷程度を 診断し然るべき処置を受けてから耳鼻科医の 手によって線密な創傷処理と繊細な縫合処置を
受けた方が余程その予後，すなわち術後に残る 瘢痕拘縮や支持組織の变形が少なくてすむので はないかと思っている。

一般に顔面外傷でまず目につく症状は鼻出 血, 呼吸困難, 口からの出血, 顔面軟部組織の 腫脹，あるいは支持組織の位置の異常による顔 面の変形である。受傷直後であれば顔面軟部組 織の腫脹は左程目立たなく，外鼻錐体の形態異 常も直ちに䛦断でき，鼻出血に対する処置は耳 鼻科医にとって日常行なっている操作であるが ゆえに鼻鏡で鼻腔内の所見をみれば出血部位の 確認は容易である。

若し顔面外傷患者を耳鼻科医が最初に診察し たら自らの手によって修復処置を施すか，ある いは大きな損傷を伴っていて全身麻酔の下に他 の科の医陑の協力在要とする場合でも必要な 処置は施してから紹介するだけの知識と積極的 な診療態度を今後更に一層持つべきことが大切 だと私は考光ている。

比較的軽度の顔面外傷例において耳鼻科医で あれば誰れでも当然初期治療を行なう事ができ るはずである。このような場合に用いられる簡 単な器具と操作について原則的なととを述べ, 他の問題については後述の各分担演者の書かれ た内容を御参照いただきたいと思う.

まずどの様な外科的処置においてもそれに適 合した器械器具が必要である. 鼻骨および上顆

Symposium on Facial Injury.

Yoichi Ogino.

* 聖マリアンナ医科大学形成外科学教室 
骨前頭突起の骨折, 鼻中隔骨折に対しては従来 ランゲンベック剝離子が良く使用されて来たが Walsham 鈿子または Asche 型鈿子を用意し ておくと骨片の移動の整復に便利である.

創の縫合に必要な鑷子は組織を確実に把握 ししかも組織に無用の損傷を与え奴ようにす るために耳鼻科用鑷子を用いるよりは $\mathrm{Mc}$ Indoe 型形成鑷子は皮下組織, 筋肉層の保持, 粘膜弁の保持および皮膚の縫合に便利であり， また hook 型鑷子は皮膚および皮下組織の保持 および縫合に適している、縫合糸は針付ナイ口 ン糸の $5 \sim 0 ， 6 \sim 0$ 程度がよい.

剪刀も形成用尖鋭および彎剪刀および尖端が

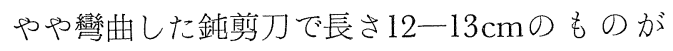
最も使い易い. 并状になった皮弁の保持, 適合 の度合を目測するのに hook（単，双）が意外 に利用度が大きい。

また持針器は従来耳鼻科でよく用いられて来 た Mathieu 型のものよりも種々の大きさの Hegar 型の持針器の方が針付ナイロン糸によ る縫合操作に䈏している。

どのような手術器械を用いても立派な手術結
果が得られればそれで十分であるといら方があ るかも知れないが，手術部位により，また創の 処理の目的に応じ。最も使い易く，無駄な洔間 を費すことなく処置ができるものを用うべきで あろう。確実な創傷処理を行ってから十分な止 血処置, 創の固定を目的として形成外科では術 後の圧迫固定に重点がおかれる。顔面のように 繃帯が思うようにでき部位では消毒した $3 \mathrm{M}$ テープを創の方向に交るように何枚も貼布して おく.

外傷の際の治療では一般的に外観的な形態の 修復に重点がおかれがちであるが，外鼻と直接 関連むる鼻腔および副鼻腔, 咽頭腔などにおよ ぼす機能的な障害を無視してはならない。また 感染の予防, 粘膜の腫脹による呼吸, 食物の摂 取などの障害にも考慮を払い患者の全身管理も 忘机てはならないのが外傷治療の要点であろ 亏.

原稿到着：炤和49年11月29日

(别刷請求先: 狄野 洋一

事213 神奈川県川崎市高渄区管生2095

留マリアンナ医科大学形成外科学教室 